UDK 821.163.42.09 Čedomil, J. Izvorni znanstveni članak

Primljen: 9. 5. 2013.

Prihvaćen za tisak: 28. 10. 2013.

\title{
FRANCUSKI IZVORI I UZORI DR. JAKOVA ČUKE (PREMA ČUKINOM FONDU U ZNANSTVENOJ KNJIŽNICI U ZADRU)
}

\begin{abstract}
U radu se daje pregled književnokritičkog rada dr. Jakova Čuke (1868 1928), poznatijeg pod književnim pseudonimom Jakša Čedomil, u svjetlu njegovih francuskih uzora (Taine, Brunetière, Saint-Beuve, i drugi), na koje se on u svojim kritikama pozivao, i na temelju izvora koji se nalaze u Fondu Čuka pohranjenom u Znanstvenoj knjižnici u Zadru, a koji sadrži 112 francuskih autora i 290 naslova na francuskom ili prevedenih na strane jezike (talijanski, njemački, hrvatski). Poznavanje tih autora priskrbilo mu je naslov "utemeljitelja hrvatske književne kritike". Sam fond predstavlja bogat izvor znanja o francuskoj književnosti XIX. stoljeća.
\end{abstract}

KLJUČNE RIJEČI: Jakov Čuka, Jakša Čedomil, književna kritika, francuska književnost.

Dr. Jakov Čuka po mnogočemu je neobična pojava, počevši od samog imena i prezimena po kojima je poznat široj javnosti - Jakša Čedomil, što je zapravo samo jedan od pseudonima pod kojima je objavljivao svoje tekstove. ${ }^{1}$ Toj javnosti je poznat kao književni kritičar, što je on i bio, ali samo od 1887. do 1903. godine, a manje - ili uopće nikako - kao specijalist za crkveno pravo čije je znanje bilo od velike koristi u pripremi nikad ratificiranog konkordata između Svete Stolice i Kraljevine Srba, Hrvata i Slovenaca. Nije poznat ni kao prognanik iz Zadra nakon talijanske okupacije 1918., koji je svoje utočište našao u Splitu, ni kao - makar kratkotrajno - ravnatelj Zavoda svetog Jeronima u Rimu, stoljetne ustanove koja je odigrala veliku ulogu u kulturnom i političkom životu Hrvata. ${ }^{2}$

Najviše se ističe njegovo poznavanje i pisanje o francuskoj književnosti i književnoj kritici koja mu je pribavila laskavu titulu "osnivača moderne književne

\footnotetext{
${ }^{1}$ Jakov Čuka se, između ostalog, potpisivao i drugim psudonimima: fra Čedomil, Paško Zagorčić, J. C, D. C, U. G, X, ***, itd.

2 Sudeći po Čukinoj bibliografiji koju je objavio Andrija Radoslav Glavaš u svoj knjizi Jakša Čedomil,osnivač moderne hrvatske kritike (214-219), Čuka je i nakon 1903. - kada se je prestao baviti književnom kritikom - nastavio pisati o raznim drugim temama u Narodnom listu, Il Popolo, Smotri Dalmatinskoj, Novom dobu, itd. Ukupno 80 naslova. Ti bi se napisi mogli svesti na nekoliko tema: Strossmayer, Zavod sv. Jeronima u Rimu, političke prilike u Zadru i Dalmaciji, jezična politika u Dalmacji i pitanje glagoljice, putopisi, položaj naroda, crkveno pravo. Sve te teme zavrjeđuju posebnu pozornost analitičara.
} 
kritike" (Glavaš 1942). Da stvar bude još jednom neobična, Jakov Čuka se najviše bavio talijanskom i hrvatskom, pa čak i ruskom, književnosti, njegov prvi uzor bio je Talijan De Sanctis a najomiljniji hrvatski književnik Ksaver Šandor Gjalski.

"Taj lucidni, prerano sazreli mladić, s usađenim osjećajem za književnost i istančanim literarnim ukusom", kako ga opisuje Nevenka Košutić-Brozović (1976: 274), od malih nogu pokazivao je znakove izuzetne nadarenosti pa je već u trećoj godini iz svog rodnog Zaglava na Dugom otoku poslan na odgoj i školovanje. Tamo je završio osnovnu školu i - preskočivši nižu - izravno upisao višu gimnaziju koju su tada vodili isusovci. Studij teologije završio je dvije godine prije nego je mogao biti zaređen za svećenika. Čekajući svećeničko ređenje dvije godine završio je kanonsko pravo s diplomom doktora. Međutim, izgleda da je veliki dio vremena u Rimu posvetio čitanju talijanskih i francuskih djela, a nabavio je i respektabilnu osobnu knjižnicu. Ta knjižnica čini danas Fond Čuka u zadarskoj Znanstvenoj knjižnici, dragocijenu riznicu podataka o Čukinim izvorima i književno-kritičkim preferencijama. Prema sadržaju tog fonda, koji sadrži 1124 naslova knjiga, pokušati ćemo u ovom radu dati opis njegovih francuskih izvora i uzora predstavljenih u Fondu pod 112 imena i oko 290 naslova. Prije toga predstavit ćemo Čukin životni put u vidu tabelarnog sinoptičkog i kronološkog pregleda, potom ćemo iznijeti što su o našoj temi rekli neki hrvatski kritičari novijega doba; predstaviti ćemo i analizirati njegove radove koji izravno govore o francuskoj književnosti i književnoj kritici, ali i neke druge koji se odnose na druge književnosti a temelje se na francuskoj književnoj kritici.

Dodajmo na kraju ovoga kratkog uvoda glavne orise okruženja, mjesnog i književno- povijesnog u kojem je djelovao Jakša Čedomil, tj. Jakov Čuka kao književni kritičar. U književno-povijesnom pogledu u Francuskoj je to bilo vrijeme realizma, naturalizma, simbolizma, dekadencije i idealizma (u svjetonazorskom pogledu pozitivizma i darwinizma), a u Hrvatskoj doba realizma, naturalizma i Moderne. U to vrijeme u Zadru su živjeli i djelovali Ivo Vojnović (1889. - 1891., 1899. - 1903.), Vladimir Nazor (1899. - 1903.), Milan Begović (1888. - 1890.), Petar Kasandrić (1887. - 1918.). Bilo je to vrijeme kad je Zadar bio istaknuti centar književnog života u Hrvatskoj. ${ }^{3}$

\section{KRATKI PRIKAZ ŽIVOTNOG PUTA DR. JAKOVA ČUKE}

Radi lakšeg razumijevanja i praćenja teksta dati ćemo odmah na početku sinoptički pregled Čukinoga života i rada sastavljenog prema Kero 2001 (životopis) i Milanja 1985 (bibliografija).

\footnotetext{
${ }^{3}$ Više o mjestu Zadra u hrvatskoj književnosti kraja XIX. i početka XX. stoljeća vidi kod: Rados 2011 i Košutić-Brozović 1976.
} 


\begin{tabular}{|c|c|c|}
\hline Godina & Događaji u životu & Književni događaji \\
\hline 1868 & 16. VII . rođen u Zaglavu & \\
\hline $\begin{array}{l}1880- \\
1884\end{array}$ & V-VIII. razr. Zmajević & Dopuštena i nedopuštena lektira \\
\hline $\begin{array}{l}1884- \\
1888\end{array}$ & $\begin{array}{l}\text { Bogoslovno sjemenište u } \\
\text { Zadru }\end{array}$ & $\begin{array}{l}\text { 1887. Hrvatska mladež i "Zvonimir", Prigodom } \\
\text { nove knjige, Ivo Vojnović, hrvatski pripovjedač, } \\
\text { Iskrice (Josipa Draženovića); 1888. O romanu (sve } \\
\text { u Narodnom listu) }\end{array}$ \\
\hline $\begin{array}{l}1888- \\
1889\end{array}$ & $\begin{array}{l}\text { Zavod sv. Jeronima, } \\
\text { Papinski rimski Licej, } \\
\text { Institut za staroslavenski } \\
\text { Doktorat kanonskog prava }\end{array}$ & $\begin{array}{l}\text { U registraturi(Hrvatska, 1889), Talijansko } \\
\text { pjesništvo (Vijenac, 1889,12 priloga), Antonio } \\
\text { Fogazzaro (Prosvjeta, 1889) }\end{array}$ \\
\hline 1890 & $\begin{array}{l}\text { Profesor hrvatskog u } \\
\text { Zmajeviću } \\
\text { Svećeničko ređenje (16.11), } \\
\text { Mlada misa u Bibinjama }\end{array}$ & $\begin{array}{l}\text { Un poeta serbo (Zmaj J. Jovanović) (Ransegna } \\
\text { della letteratura italiana et straniera, 1890) }\end{array}$ \\
\hline $\begin{array}{l}1890- \\
1892\end{array}$ & Kapelan Sv. Šime & $\begin{array}{l}\text { Zmaj Jovan Jovanović, Naše književne nevolje i } \\
\text { kritika, Eugenij Kumičić, Ksaver Š. Gjalski, Mato } \\
\text { Vodopić, Ante Tresić-Pavičić, Nešto o seoskoj } \\
\text { noveli (Iskra, 1891); Gospodin J.M. O...jić i } \\
\text { "kritički Falstaff" (Narod, 1891); Un romanziere } \\
\text { croato Djalski, Un poeta serbo, Zmaj Jovan } \\
\text { Jovanović (Fanfulla della Domenica, 1892), Iz } \\
\text { varmeđinskih dana, Talijanski roman (Iskra); } \\
\text { Pamet i srdce, Percy Bisshe Shelley (Vienac, 1892) }\end{array}$ \\
\hline $\begin{array}{l}1892- \\
1895\end{array}$ & $\begin{array}{l}\text { Kancelar u } \\
\text { Nadbiskupijskoj kuriji }\end{array}$ & $\begin{array}{l}\text { Važno književno pitanje, Hipolit Taine, Osvit, } \\
\text { Epska pjesma fra Grge Martića (Iskra, 1893); Il } \\
\text { momento presente del romanzo italiano, Nel sogno, } \\
\text { Procelle dell'anima (Roma letteraria, 1893); Per } \\
\text { Bernardo Celentano (La Sentinella Arpina, 1893); } \\
\text { La dottrina di L. Tolstoj (Fanfulla della Domenica, } \\
\text { 1894); } \\
\text { O "Radmiloviću" (Vienac, 1895) }\end{array}$ \\
\hline 1895 & $\begin{array}{l}\text { Profesor vjeronauka } \\
\text { na Višoj gimnaziji u } \\
\text { Zadru, rezid. kanonik } \\
\text { Metropolianskog kaptola } \\
\text { u Zadru (1904), suradnik } \\
\text { nadbiskupa Novaka, } \\
\text { Rajčevića, Dvornika, } \\
\text { Pulišića }\end{array}$ & $\begin{array}{l}\text { Književne radnje grofa Lava Tolstoja, Vjerska, } \\
\text { filozofska i moralna djela Tolstojeva (Nada, 1896); } \\
\text { Gabrielle d'Anunzio (Nada, 1897), Urednicima } \\
\text { "Mladosti" (Narodni list, 1897), Hrvatski } \\
\text { književni listovi, Pop Stjepan Buzolić, O hrvatskoj } \\
\text { narodnoj književnosti (Katolička Dalmacija, 1897), } \\
\text { Kritički rad Marka Cara, Parnasijanci i Fr. Coppée } \\
\text { (Novi viek, 1897); } \\
\text { Novi pojavi na književnom obzorju (Narodni } \\
\text { koledar Matice Dalmatinske, 1898), Mladji } \\
\text { naraštaj u književnosti, Današnja mladež, } \\
\text { Suvremena talijanska književnost, Amo tamo po } \\
\text { francezkoj književnosti, Osman-Azis, Vladimir } \\
\text { Borotha, hrvatski pripovijedač, Odgovor dr. J. } \\
\text { Čuke (Jakša Čedomil), Za procvat hrvatske knjige } \\
\text { (Novi viek, 1898); } \\
\text { Friedrik Nietzche i njegova nauka (Nada, 1899), } \\
\text { Antonio Fogazzaro (Prosvjeta, 1899), Silvije Str. } \\
\text { Kranjčević (Novi viek, 1899), Janko Leskovar, } \\
\text { Mihovil Nikolić (Vienac, 1899), Risposta alla } \\
\text { inchiesta sull'arte e la letteratura contemporanea in } \\
\text { Italia, (Il Marzocco (1899) }\end{array}$ \\
\hline
\end{tabular}




\begin{tabular}{|c|c|c|}
\hline Godina & Događaji u životu & Književni događaji \\
\hline 1900 & & $\begin{array}{l}\text { Jovan Hranilović, hrvatski pjesnik (Nada), } \\
\text { Giovanni Pascoli (Život), Stari i Mladi (Vienac), } \\
\text { Tucić-Nikolić: "Knjiga života" (Prosvjeta), } \\
\text { Individualizam u književnosti (Prosvjeta), Pred } \\
\text { viekom (Prosvjeta), Neera (Nada), Diljem doma } \\
\text { (Prosvjeta), Discours de combat (Vienac), Životu } \\
\text { (Vienac), A. Petravić, "Pjesme" (Prosvjeta), Iz } \\
\text { talijanske književnosti (Zivot), O lijepoj knjizi } \\
\text { (Katolički kongrers), Knjiga "Boccadoro" i } \\
\text { "Slavenske legende" (Vienac), Manje programa, } \\
\text { više djela (Vienac). }\end{array}$ \\
\hline 1901 & & $\begin{array}{l}\text { Novije pjesništvo u Francuskoj (Nada), Pregled } \\
\text { hrvatske književnosti, Solovjev-Mereškovski-Gorki, } \\
\text { Matica Hrvatska - Tri pripovijedača, Politeo, } \\
\text { Jeretov, Ivanov, Varia, Za stogodišnjicu Stjepana } \\
\text { Ivičevića, Nakon } 400 \text {, Tri pjesnika - Novije knjige } \\
\text { Časopisi (sve u Glasniku Matice Dalmatinske). }\end{array}$ \\
\hline 1902 & & $\begin{array}{l}\text { Nove pripovijesti, Fra Grga Martić - Nove knjige } \\
\text { Književni časopisi, Finis reipublicae, Knjige i } \\
\text { časopisi, Narodni duh i najnovija književnost, } \\
\text { Novija hrvatska lirika, Mrtvi i živi (Glasnik Matice } \\
\text { Dalmatinske). }\end{array}$ \\
\hline 1903 & & $\begin{array}{l}\text { Il conte Tolstoj e le sue opere (Rivista politica e } \\
\text { letteraria). }\end{array}$ \\
\hline 1910 & $\begin{array}{l}\text { Nema podataka o životu } \\
\text { i radu }\end{array}$ & \\
\hline 1919 & $\begin{array}{l}\text { Svećenik Splitske } \\
\text { nadbiskupije } \\
\text { Član Komisije za pripremu } \\
\text { konkordata u Beogradu }\end{array}$ & \\
\hline 1922 & $\begin{array}{l}\text { Razriješen dužnosti } \\
\text { zadarskog kanonika; } \\
\text { Orden sv. Save III. reda }\end{array}$ & $\begin{array}{l}\text { Moj životopis (Almanah Vedre hrvatske duše, } \\
\text { 1922) }\end{array}$ \\
\hline 1924 & $\begin{array}{l}\text { Prepozit Stolnog kaptola u } \\
\text { Splitu }\end{array}$ & \\
\hline 1925 & $\begin{array}{l}\text { Generalni vikar nadb. } \\
\text { Kvirina Bonefačića }\end{array}$ & \\
\hline 1928 & $\begin{array}{l}\text { Rektor Zavoda sv. } \\
\text { Jeronima u Rimu }\end{array}$ & \\
\hline 1928 & $\begin{array}{l}\text { 1. studenog umro u } \\
\text { Zavodu }\end{array}$ & \\
\hline
\end{tabular}


Ovim naslovima, ukupno 90, treba dodati stručnu i pravnu bibliografiju koju je objavio Andrija Radoslav Glavaš. Kako ona nije relevantna za našu temu, izostavili smo je. Napomenimo još samo da je Mate Ujević objavio dva sveska izabranih članaka Jakova Čuke, i to: Prikazi i rasprave (1943) i O književnosti (1944).

Zavidan je i broj časopisi u kojima je Čuka surađivao: Narodni list, Iskra, Vienac, Narod, Fanfulla della Domenica, Roma letteraria, La Sentinella Arpina, Nada, Katolička Dalmacija, Novi viek, Narodni koledar Matice Dalmatinske, Prosvjeta, Il Marzocco, Život, Glasnik Matice Dalmatinske, Vedre hrvatske duše, Korablja, Il Popolo.

\section{KNJIŽEVNI KRITIČARI O JAKŠI ČEDOMILU I NJEGOVIM FRANCUSKIM IZVORIMA I UZORIMA}

Kad se govori o Jakovu Čuki, Jakši Čedomilu kao kritičaru, dobiva se dojam da je on najpoznatiji zbog toga što je u hrvatsku književnu kritiku unio elemente francuske književne kritike. Međutim, u napisima o Jakši Čedomilu govor o tome je relativno kratak i sumaran.

Ne iznoseći ovdje mišljenja Čukinih suvremenika (Petravić, Jurin), mi ćemo navesti najprije ono što je napisao Andrija Radoslav Glavaš u prvom opširnijem i sustavnijem djelu o Čuki, Jakša Čedomil, osnivač moderne hrvatske kritike, objavljenom 1942. Glavaš je prvi imao potpuni uvid u Čukinu osobnu knjižnicu i pismenu ostavštinu, pa se je obilno koristio njegovim zabilješkama na marginama knjiga ili na karticama i u posebnim bilježnicama. Iako knjiga nosi u naslovu Čukin književni pseudonim, autor se dotiče i drugih vidova Čukine djelatnosti pa i razlozima prestanka bavljenja književnom kritikom, tema koja prelazi granice književne kritike. ${ }^{4}$ Nas je posebno zanimalo 8. poglavlje "Jakša Čedomil i europska kritika - Utjecaji" (129-164) iz kojeg donosimo glavne misli.

Pozivajući se na Marjanovića i Petravića Glavaš je o Čuki napisao rečenicu koja će se kasnije često ponavljati kod drugih autora a odnosi se na prvu periodizaciju Čukinog kritičarskog opusa:

"Zapravo [piše Glavaš] utjecaj talijanske kritike pretežan je u prvim godinama njegova rada, nekako do godine 1891., a poslije se osjeća sve veći, i napokon isključivi utjecaj Francuza" (131). Zanimljiva je i bilješka uz ovu rečenicu u kojoj Glavaš na temelju uvida u kartice koje je Čuka ispisivao za studiju o talijanskom romanu zaključuje da je Čuka već "krajem osamdesetih godina poznavao vodeće francuske kritičare Bourgeta i Brunetièrea". Isti zaključak izvlači iz analize Čukine osobne knjižnice kad kaže: "Dok francuske kritičare, pa i neznatnije, ima u cjelini, talijanskih je manje."(132) Međutim, treba napomenuti da sadržaj osobne knjižnice, iako važan, ne mora uvijek biti i relevantan pokazatelj. To bi se prije svega moglo odnositi na odnos talijanskih i francuskih autora. Treba imati na pameti da se radi o privatnoj knjižnici koja je kupljena novcem vlasnika, a u takvim slučajevima kupuju se knjige koje su nam inače teško dostupne - ili će nam u dogledno vrijeme biti

\footnotetext{
${ }^{4}$ O tome je Glavaš posebno pisao u Hrvatskoj reviji 1942, br. 3.
} 
teško dostupne (nakon povratka u Zadar, u Čukinom slučaju). Manje dostupne ili teško dostupne knjige za vlasnika su bile one francuskih autora. Naprotiv, knjige talijanskih autora su se mogle naći u zadarskim knjižarama i knjižnicama. Ne treba zaboraviti da je Čuka živio u Austro-ugarskoj monarhiji, da je studirao u Kraljevini Italiji a da su se francuske knjige tiskale u III. Republici (francuskoj). To objašnjava činjenicu da se mnoga djela francuskih autora nalaze u talijanskim i njemačkim prijevodima. Isto vrijedi i za brojčanu zastupljenost jednog autora u knjižnici. Ona može biti simptomatična, čak i apsolutno relevantna, ali se ne može uzeti kao apsolutno pravilo. U tom pogledu zanimljivo je usporediti jedan Glavašev navod iz Čukinih Uspomena u kojem se govori kako je ovog "jedan kritičar opsjenuo". Radilo se o Hyppoliteu Taineu. Kasnije ćemo vidjeti da se Čuka često pozivao na Tainea, da mu je čak napisao i nekrolog te da je u Uspomenama napisao da mu je žao što nije o njemu napisao opširniju studiju. A u njegovoj knjižnici nalazimo samo jedno Taineovo djelo - Histoire de la littérature anglaise (1-5). To ne mora značiti da Čuka nije čitao i druga Taineova djela. Isto vrijedi i za ostale autore.

Glavaš slijedi Čuku u književnim, kritičarskim i ideološkim meandrima romantizma, realizma, naturalizma, darwinizma, pozitivizma, humanitarnog realizma i idealizma, dakle vanjskih utjecaja i njegovih vlastitih mišljenja i stajališta, njegovih odnosa prema stremljenjima i strujanjima u talijanskoj, francuskoj, engleskoj i ruskoj književnosti, njegov odnos prema književnicima Manzoniju, Zoli, Walteru Scottu i Turgenjevu, književnim kritičarima Bourgetu, Brunetièreu, Taineu, Brandèsu, Vogüéu, Doumicu, Pellissieru (ima ih više, u tekstu se javljaju s jednim i s dva 'l', budući da nema imena uz prezime, a više je autora 19. stlj. od kojih se neki pišu s jednim, a neki s dva 'l' pa pitati autora na koga točno misli), De Sanctisu, Celentanu, Panzacchiju itd.

Glavaš ulazi u finese Čukinog kritičarskog profila. To se jasno vidi u njegovoj analizi Petraviće kvalifikacije "naš hrvatski Brunetière". "To treba uzeti s oprezom", kaže Glavaš. On priznaje da je "Čedomil doista obilno uzimao od Brunetièrea. Tako je Discours de combat "jednostavno prepričao i primijenio na naše prilike", ali je uzimao samo ono što se izravno ticalo hrvatskih prilika. Dalje pobija Petravićevu tvrdnju dokazujući i pokazujući u čemu je Čuka bio svoj u vrednovanju npr. književnih vrsta, u važnosti i mjestu darwinizma i pogledima na stariju književnost, na ulogu kritičara u književnosti i književnika u kritici, na odnos morala i književnosti. Opću ocjenu Jakše Čedomila možemo naći u zaključku koji Glavaš donosi pri kraju poglavlja kad, nakon nabrajanja francuskih i talijanskih književnika i kritičara piše:

Sve ove skupine i imena Čedomil je primao bez ikakvih predilekcija. Izabirao je, što mu je najviše odgovaralo. Uopće za Čedomila nije bilo važno, kojem pravcu pripada kritičar, samo ako je imao elemenata, koji su bili valjani i upotrebljivi za suđenje u književnosti (163).

Od novijih književnih kritičara koji su pisali o Čuki kritičaru navesti ćemo imena kao što su Jakša Ravlić, Vinko Antić, Ante Franić, Nada Beritić, Mladen Dorkin, Cvjetko Miljanja, koji se javljaju u ciklusima koji slijede gotovo u pravilu obljetnice njegove smrti. 
Tridesetu obljetnicu smrti obilježila je Riječka revija, br. 6, 369-409 u kojoj nalazimo uvodnu napomenu Berislava Lukića u Čukine Uspomene, koje se jedine tiču naše teme. Ostali prilozi se odnose na pojedinosti iz njegova života, kao što je svjedočenje njegovog sinovca Marina Čuke pod naslovom "Iz života Jakše Čedomila" (392-395), u kojima se najviše govori o razlozima prestanka bavljenjem književnom kritikom, sve popraćeno dvama pismima njegovih crkvenih poglavara, nadbiskupa Rajčevića i njegovog zamjenika Borzattija, a Vinko Antić je objavio i bilješkama popratio "Kranjčevićeva pisma Jakši Čedomilu" (396-409). U svojim Uspomenama koje je počeo pisati 17. rujna 1911. Čuka na nekoliko mjesta spominje francuske kritičare. Najprije Brandèsa, ako ga možemo smatrati Francuzom, u povodu Marjanovićeve knjige "Iza Šenoe": "On je čedo Brandèsa u metodi prosuđivanja književnosti, a i uvod sjeća na uvod Brandèsova djela o glavnim strujama književnosti XIX v." (374). Piše i kojim je redom proučavao moderne kritičare: "De Sanctis je bio izmedj prvih što sam proučio, pak zatim Francuze Sainte-Beuvea, Tainea i ostale modernije" (376). Na jednom mjestu spominje Bourgeta u vezi s Borothom, a Brunetièrea na više mjesta izjašnjavajući se kao njegov "gorljivi pristaša" (388) Ali će već na sljedećoj stranici ispričati jedno svoje osobno neugodno iskustvo s Brunetièreom koje ćemo iznijeti pri kraju ovog rada.

Istom prilikom je Jakša Ravlić objavio u Zadarskoj reviji br. 4/1958, 299-304 svoj članak "Jakša Čedomil (1868-1928)" u kojem se dotiče i naše teme. Spominje Sainte-Beuvea i Tainea te članak "Naše književne nevolje i kritika" pa zaključuje:

Sve nam ovo svjedoči da je Čuka shvaćanje književnosti na Zapadu htio presaditi $\mathrm{k}$ nama, da je pošao modernim putem. Kasnije će svojim uzorima pridodati još jedno ime: Brunetière (1849-1906), prikazujući njegove "Discours de combat (Vienac 1900, br. 16)" (302).

U istom zadarskom časopisu Vinko Antić će 1959. u dva nastavka objaviti svoj rad "Silvije Strahimir Kranjčević u Jakša Čedomil" (286-298, 390-399) u kojem, navodeći Čukine priloge u sarajevskoj Nadi, između ostalih navodi rad pod naslovom "Novije pjesništvo u Francuskoj (Parnasijanci, Dekadenti, Simbolisti)", Nada, VII/1901, br. 4,5.

Zadarska revija je obilježila i 40. obljetnicu Čukine smrti objavivši dva rada od kojih onaj Ante Franića ("Jakša Čedomil (1868-1928)", 258-264) samo usput spominje F. Coppéea i Zolu u vezi s Čukinim mišljenjem o Kumičiću.

Za razliku od Franića, Nada Beritić u svom radu "Čukina biblioteka" (465472) daje niz podataka korisnih za našu temu. Tako, govoreći o Čukinoj osobnoj knjižnici Beritić, nakon što je spomenula časopis Mercure de France, piše:

U Čukinoj knjižnici sačuvao se nešto manji broj knjiga pisanih njemačkim i francuskim jezikom nego što je to bilo u predhodnim skupinama/talijanskoj i hrvatskoj/ (468).

$\mathrm{Na}$ istoj stranici nalazimo relativno dugi stavak o temi koja nas ovdje zanima donoseći gotovo cjeloviti popis francuskih književnih kritičara o kojima ćemo govoriti u idućem poglavlju. 


\section{Ovdje donosimo nešto duži izvadak:}

Među stranim knjigama Čukine knjižnice najcjelovitiju i najvažniju skupinu predstavljaju djela francuskih kritičara brižljivo sakupljana od vremena Čukina studija u Italiji pa kroz cijeli period njegove književne aktivnosti. Uz djela Zole, de Vogüéa na kojima je zabilježena 1887. i 1888. godina kao vrijeme nabave, nižu se u kontinuiranom slijedu najznačajniji predstavnici francuske kritike: Taine, Sainte-Beuve, Pellissier, Brunetière, Lemaître, Faguet, Doumic, Bourget, Morice, Recolin, France i to ne sa po jednim djelom nego po nekoliko čak i do deset različitih djela pojedinih autora. Svakome od njih posvetio je Čuka dužnu pažnju: savjesno čitao pojedina djela, bilježio odmah u samoj knjizi primjedbe i zapažanja i, gotovo redovito, na posljednjoj stranici knjige iznosio, kao rekapitulaciju pročitanog djela, kao podsjetnik koji mu može koristiti u radu, sadržaje pojedinih poglavlja i osnovne piščeve misli. Od svakog od njih Čuka je učio, uzimao, usvajao već prema tome koliko su mišljenja pojedinih kritičara mogla da se uklope u tokove njegova književnog razvitka i njegovih pogleda na književnost. I dok je utjecaj talijanske kritike bio presudan za Čuku, jer je potaknuo i razvio njegove sklonosti prema književnoj kritici te mu pružio i prve poglede i pojmove o njoj, dotle je utjecaj francuske kritike na Čuku bio dominantan (468).

Autorica iznosi podatke o Čukinoj korespondenciji deponiranoj u Znanstvenoj knjižnici u Zadru te piše:

Od nje su se očuvala 262 pisma. Izuzev nekoliko pisama na francuskom jeziku sva su ostala pisana našim i talijanskim jezikom.

Beritić spominje i prijevod s francuskog Pisma jednog župnika pohranjenog u neobjavljenim Čukinim tekstovima (471). Taj Čukin nedovršeni rukopis ne dovodi u vezu s prijevodom knjige koja će 1917. izići u izdanju Zbora bogoslovne mladeži u Zadru, bez spominjanja Čuke, pod naslovom Pisma seoskog župnika francuskog autora Yvesa le Querdeca. Taj rukopis spominje i A. R. Glavaš ali navodi pogrešan naslov izvornika, na što ćemo se osvrnuti nešto kasnije $s$ više pojedinosti.

Kad već govorimo o francuskom dijelu Čukinoga fonda, navedimo nekoliko zanimljivih podataka o zastupljenosti francuskih autora prema broju njihovih djela. Najzastupljeniji je Scribe (18 naslova), Sardou (16), Brunetière (15), Vogüé (14), Zola (10), Bourget (9), Hugo (8), Dumas Sin (8), Lemaître (7), Faguet (7), Fensegrive-Lespinasse (5), Anatole France (4), Lamartine (4). Ostali su zastupljeni s po jednim naslovom, među njima i Hyppolite Taine i Ernest Renan. Zanimljivo je napomenuti da u njegovoj osobnoj knjižnici nema imena kao što su obraćenici i katolički pisci Bernanos, Péguy, Psychari, James, Claudel, Rivière, i drugi.

Cvjetko Milanja je 1986. objavio drugu sustavnu studiju na hrvatskom jeziku o Jakši Čedomilu pod istim imenom - Jakša Čedomil. ${ }^{5}$ Kod njega možemo naći mnogo podataka o onome što su drugi rekli o Čuki književnom kritičaru (Prohaska, Barac, Graciotti) ali i njegovih osobnih zapažanja. Posebno treba istaći njegovu periodizaciju Čukine književno-kritičke djelatnosti koju od dijeli u četiri faze. Prva faza traje od prvih radova do povratka sa studija u Rimu (1887. - 1890.). Druga faza ide od 1890. - 1893., a treća od 1893. - 1900. Četvrta i zadnja faza obuhvaća, po

\footnotetext{
${ }^{5}$ Osim Glavaša i Milanje posebnu studiju o Jakši Čedomilu napisao je i S. Graciotti ali na talijanskom jeziku pod naslovom La critica di Jakša Čedomil (1959). Na tu se knjigu nismo osvrnuli u ovom radu.
} 
mišljenju Milanje, stvarno godinu 1901. i 1902. budući da mu je posljednja kritika objavljena u travnju 1903. godine. Čitatelj će, imajući u vidu ovu periodizaciju, donekle moći utvrditi i radove navedene u sinoptičkoj tablici, koji pripadaju odgovarajućim fazama. U svom kratkom uvodu Milanja se osvrnuo na dotadašnja mišljenja o Čedomilu. Posebno ističe Barca i njegovo "literarno-historijsko stajalište" lišeno komparatistične dimenzije. Hvali metodu i tekstualno istraživanje Graciottija, nema ništa dodati njegovim argumentima u komparatističkom presjeku njegova rada, ali mu zamjera da je potpuno zanemario vrednovati ulogu koju je Čedomil imao u hrvatskoj književnoj kritici te mu predbacuje da je pokušao "dezavuirati i umanjiti Čedomilov kritički rad". Malo je neobičan Milanjin pokušaj govora "o Čedomilovu spontanom, implicitnom marksizmu".

U ovom dijelu a i kasnije najgore je prošao Glavaš koga Milanja često kritizira. Za njegovu monografiju kaže da "već u naslovu ima apodiktičku tvrdnju preuzetu iz Petravićeve studije; nastala u teškim ratnim uvjetima, pisana je s podosta ushita i pretjerane pa dakle i nekritične simpatije prema Jakši Čedomilu što može biti zgodno ali ne i znanstveno ili interpretativno primjereno Čedomilovou kritičkom diskursu" (11). Nakon kratkog pregleda književne kritike prije Jakše Čedomila, autor daje prikaz njegove kritike po već spomenutim fazama, u čemu slijedi Graciottija ali i njegov komparatistički pristup, koji su obojica preuzeli od Glavaša. Tu je i obvezna tema o uzrocima prestanka pisanja književnih kritika i zaključak iza kojeg dolaze, malo neobično, još dva poglavlja: "Tradicijski kontinuitet" i "Estetička pozicija" Jakše Čedomila. Studija je opremljena Čedomilovom bibliografijom koja ide samo do 1903. i sadrži samo književne kritike, te vrlo korisnom literturom o Jakši Čedomilu.

Najnovije spominjanje Jakše Čedomila nalazimo u knjizi Časopis "Iskra" Mladena Dorkina iz 2011. godine. Čedomil je najpoznatiji suradnik tog časopisa u njegovom drugom izdanju od 1891. - 1894. i kao takav nezaobilazna tema i pojava. Po Milanji to je već njegova druga faza, ali zapravo početak njegove pune afirmacije. Dorkin ovako opisuje njegove početke:

Mlad i načitan, oduševljen modernim teoretskim načelima europske suvremene kritike, nadasve Sainte-Beuvea i Tainea, i zaprepašten siromaštvom duha i pomanjkanjem svakog kritičarskog sluha hrvatske kritike koja mu je bila "dosadna, prazna, bedasta" i koja mu je govorila da bi bio u stanju pisati kritike "i bolje i ljepše neg svi oni koji su je pisali po našim listovima i časopisima", Jakša Čedomil započinje kritičarskim radom još 1887. u Narodnom listu radnjom "Hrvatska mladež i Zvonimir" ... (297)

Njegovu ulogu i mjesto u književnoj kritici autor sažima u dva navoda:

(...) prateći europska strujanja Jakša je Čedomil suvereno upoznao sve vodeće kritičare Zapada, ..... , i, kasnije, Sainte-Beuvea, Tainea, Brunetièrea, Zolu, on je jednako tako dobro poznavao suvremenu psihološku školu Bourgeta, koja je u francuskoj literaturi sve više uzimala maha na štetu realizma i naturalizma; a budući da je Čedomilu K.Š. Gjalski izrazito psihološki pisac u našoj literaturi, pa zbog toga i neshvaćen od naše diletantske kritike i neuke publike, on će u prikazu Gjalskoga Bourgetovu tvrdnju "da težnja za psihologijom vodi do pesimizma" uzeti za polaznu osnovu u analizi unutarnjih kriza i dilema njegovih junaka (308-309). 
Pišući svoj poznati programatski članak Jakša Čedomil iznosi kritičkoteoretska načela Taineove i Sainte-Beuveove kritke, koja postaju i njegova načela, govoreći o Kumičiću jasno podcrtava teoriju Zolina eksperimentalnog romana i poetiku naturalizma, u uvodu svoje studije o Gjalskom opširnije se osvrće na filozofiju pesimizma, a u toku radnje učestalo se poziva na Bourgetova načela i načela psihološke škole (326).

\section{4. ČUKA O FRANCUSKOJ KRITICI I KNJIŽEVNOSTI}

Ne znamo zasad kada i gdje je Čuka naučio francuski jezik. U svojim Uspomenama on vrlo rijetko i vrlo malo govori o svojim vezama s Francuskom i svojim radovima o francuskoj književnosti. Iz tih škrtih informacija doznajemo da je u bogosloviji (1884. - 1888.) čitao "tadašnje francuske i talijanske pisce" (375). Za taj period imamo podatak kod N. Beritić da se u njegovom fondu nalaze djela Zole i de Vogüéa s naznakom godine nabave 1887. i 1888. U to vrijeme je počeo, po svojem priznanju, čitati talijanske pisce a onda "Francuze Sainte-Beuvea, Tainea i ostale modernije" (376), a kod Iva Vojnovića primijetio je "duh i ukus francuskih tadašnjih pripovjedača" (377). U Rimu (1888. - 1890.) je uz hrvatsku "pratio i francusku knjigu" (378). N. Beritić kaže da francuske knjige pristižu kontinuirano. Katalog njegovog fonda broji više od sto imena francuskih autora i više od 290 naslova njihovih knjiga, od kojih su neke u njemačkom i talijanskom prijevodu, te časopis Mercure de France, koji je čitao "i ako mi se u pravcu nije milio", piše on u Uspomenama.

Za potrebe našeg izlaganja osvrnuti ćemo se na one radove koji se izravno bave francuskom književnom kritikom i francuskom književnošću, ali i dva rada koja govore o hrvatskoj književnosti s čestim osvrtima na francusku književnost i kritiku. Navodimo ih kronološkim redom odmah na početku: "Naše književne nevolje i kritika" (Iskra, 1891), "Ksaver Šandor Gjalski" (Iskra, 1891), "Hipolit Taine" (Iskra, 1893), "Parnasijanci i Fr. Coppée" (Novi viek, 1897), "Amo tamo po francuskoj književnosti" (Novi viek, 1898), "Individualizam u književnosti" (Prosvjeta, 1900), "Discours de combat" (Vienac, 1900), "Novije pjesništvo u Francuskoj" (Nada, 1901).

Govoreći o hrvatskim književnim nevoljama i stanju naše književne kritike, Čuka ističe kao uzor francuske književne kritičare.

Kako se kritika u ovo zadnje doba krasno razvila, poznato je svakomu, koji zna za Sainte-Beuvea i za Tainea..... Sainte-Beuve je, kako nam Zola veli, između prvih, koji je shvatio, da je potrebito iztumačiti djelo po piscu ili, da bolje rečem, kroz pisca. On bi ga postavio u njegovu sredinu, proučio mu obitelj, život, ukuse, jednom riečju, smatrao je i samu jednu stranu knjige plodom svakakvih činbenika, koje je trebalo poznavati, ako si htio izreći pravedan i podpun sud. Za njim je došao Taine i digao kritiku do znanosti....

Takvim sustavom, meni se čini, da se može doći do toga, da se po knjizi upozna pisac, njegovo doba i njegov narod, kao što je u naše doba, dokazao i učinio De Vogüé, koji nam je u djelima ruskih prvaka odkrio same pisce, njihovu dobu i život njihova doba.

To je sve De Vogüé pokušao i do sjajnih uspjeha došao. To, što ovdje ukratko nacrtah, nalazim obširno u Brandèsu. A nek ne žale čitaoci, što ću ulomak iz njegove učene razprave navesti. Novija kritika, veli on, nastoji samo o tom, da protumači, objasni 
neku tvorevinu umjenosti,određujući lemente, od kojih se sastoji. Osnivačem novije psihološke kritike je Sainte-Beuve. ... On je objasnio istinu, da se ne može ništa pojmiti ni u umjetničkom proizvodu, ni u književnom spomeniku prošlosti, ako se ne potrudimo, da prije toga razjasnimo duševnu situaciju, koja je porodila pojedini umjetnički proizvod ili književni spomenik, a da dobijemo jasan pojam o samoj ličnosti, koja je to proizvela ("O književnosti": 6-7).

U nekoliko desetaka rečenica Čuka je sažeo bitne osobine (književne) kritike u Francuskoj i naveo glavne predstavnike: Sainte-Beuve (umro 1869.), Taine (koji će umrijeti 1893.), još živući Zola (i njegova teorija eksperimentalnog romana), de Vogüé (koji je francusku kritiku primijenio na rusku književnost) i Brandès (koji je sintetizirao Sainte-Beuvea i Tainea). Nedostajao je samo Brunetière, koji je već bio na vrhuncu slave (51 godina, profesor na École Normale Supérieure, tajnik časopisa Revue des Deux Mondes, autor nekoliko knjiga). Pri kraju članka autor spominje Caroa i navodi na francuskom: (....) la critique, si elle ne fait les succès de la première heure, les consacre ou les détruit en les jugeant... Elle est l'opinion réfléchie, l'impression du second moment, celle, qui d'ordinaire, reste et, a le dernier mot dans les questions d'art et de gô̂t ("O književnosti": 13-14).

Zadržimo se za sada s nešto više pojedinosti na Sainte-Beuveu. ${ }^{6}$

Charles-Augustin Sainte-Beuve (Boulogne-sur-Mer, 1804. - Paris, 1869) školovao se u Boulogneu i Parizu. Započeo studij medicine. Surađuje u Globeu (uveo ga Paul Dubois) pišući članke iz filozofije i književnosti. Prijateljevao s Victorom Hugoom i Alfredom de Vignyjem (kritika o Odes, 1827). 1840. Bibliotekar u knjižnici Mazarine. 1844. član Akademije. 1855. spriječen držati predavanja o latinskoj poeziji na Collège de France. Od 1857. do 1861. predaje na École Normale Supérieure. 1865. senator: liberalni nastup, prekid s II. Carstvom.

Književni radovi: Tableau historique et critique de la poésie française au XVI siècle (1826.), Vie, poésies et pensées de Joseph Delorme (zbirka vlastitih pjesama) (1829.), Consolation (1831.), Pensées d'aô̂t (pjesme) (1837.), Volupté (roman) (1837.).

Književna kritika: Portraits littéraires (1832. - 1839.), Portraits des femmes (1844.), Portraits contemporains (borbeni romantizam, razilazi se s Hugoom) (1846.), Port-Royal (kapitalno djelo) (1840. - 1860.), Chateaubriand et son groupe littéraire (1860.), Causeries du lundi (1849. - 1861), Nouveaux lundis (članci objavljivani u Constitutionnel, Moniteur, Temps, 1861. - 1866.).

U kritici je nastavljač Mme de Staël i Villemaina. U kritici ne zastupa geometriju nego herborisation ("listanje") književnosti, što je evolucionističko svođenje književnosti na prirodopis, ali ne zaboravlja da postoji i stvar ukusa.

Čuka je posjedovao dva sveska njegovih Premiers lundis.

Eugène-Melchior, vicomte de Vogüé (Nice, 1848. - Paris, 1910.). Od 1871. 1882. diplomat u Carigradu, Kairu, Petrogradu. Napušta diplomaciju i surađuje u Revue des Deux Mondes i Journal des Débats. 1886. objavljuje knjigu Roman

${ }^{6}$ Podatke o francuskim autorima crpili smo u Larousse du XXe siècle. 
russe, čime se nameće kao začetnik "novo-kršćankog pokreta". Poziva pristaše idealizma na borbu protiv naturalizma u književnosti i pozitivizma u filozofiji. Upoznao Francusku s misticizmom Tolstoja i Dostojevskog. Objavio niz povijesnih knjiga tragom svojih diplomatskih službi. 1888. primljen u Francusku akademiju. Od 1893. - 1898. zastupnik Ardèchea u Nacionalnoj skupštini.

U Fondu Čuka nalazimo sljedeće Vogüéove knjige, koje ovdje navodimo u stupcu radi bolje preglednosti:

Devant le siècle, Paris, A. Colin, 1896

Heures d'histoire, Paris, A. Colin, 190-?

Histoire et poésie, Paris, A. Colin, 1898

Scènes de la vie parlementaire, Paris, Plon, Nourrit,190-

Pages d'histoire, Paris, A. Colin, 1902

Les portraits du siècle, Paris, 1883, Revue des Deux Mondes, 15 mai 1883.

Le Rappel des Ombres, Paris, A. Colin, 1900

Regards historiques et littéraires, Paris, A. Colin, 1897

Remarques sur l'exposition du centenaire, Paris, Plon, 1889

Le roman russe, Paris, Plon, 1888 (2e éd)

Sous l'Horizon. Hommes et choses, Paris, A. Colin, 1904

Souvenirs et visions, Paris, Plon, 188-? Spectacles contemporains, Paris, A. Colin, 189-?

Syrie, Palestine, Mont Athos. Voyage aux pays du passé, Paris, Plon, 1894

Među Čukinim izvorima-uzorima nalazimo i jednog Danca, Georg-Morris Cohen, zvanog Georges (1842. - 1927.), poznatiji kao Georges Brandès, autor djela Critiques et Portraits (1870.) i Grands courants de la littérature du XIXe siècle (1872. - 1882.), a u Fondu nalazimo njegova dva djela: Émile Zola i Die Hauptstromungen der Litteratur des 19. Jahrhunderts. Objašnjenje nazočnosti ovog neobičnog autora u Čukinoj knjižnici jest činjenica da je Georges sljedbenik Tainea.

Emile-Marie Caro (Poitiers, 1826. - Paris, 1887.). Filozof, spiritualist i moralist. Član Akademije moralnih i političkih znanosti, Član Francuske akademije. Više moralist nego metafizičar, više talentirani pisac nego mislilac. Pobornik Victora Cousina. U Fondu je zastupljen knjigom Poètes et romanciers (1888.)

Nekrolog "Hipolit Taine" (Iskra, 1893., 5-6: 36-37) pisan je iznimno prisnim stilom, pun dubokog poštovanja prema francuskom filozofu i kritičaru s posebnim naglaskom na osobnim karakteristikama Tainea. On ga naziva na samom početku nekrologa: "(...) jedan od najsimpatičnijih lica u ovom vieku. Velik umnik, divac pisac, dobar čovjek i iskren poštenjak..... Neprijatelja baš nije ni imao. Možda Zolu, koji mu neće znat oprostit, što je uviek protiv njemu glasovao, kad bi kandidovao za Akademiju" (6).

Nadalje autor hvali Taineovu skromnost, samotnjački život daleko od javnom života. Kratko prepričava njegov tijek života i glavna djela. O njegovom utjecaju na suvremenike kaže: 
Utjecaj Tainea na suvremenu književnost u obće, a najskoli na francuzku, bio je velik. Tako zvana naturalistička škola i Zolin eksperimentalni roman, sve se to osniva na Taineovim theorijama. Ali bi ipak pogriešio tko bi osudio s Zolom i Tainea. (!!)

Istovremeno Zolu prikazuje kao sljedbenika Tainea i opravdava Tainea za Zolina zastranjenja, kojih je sam autor veliki protivnik. Mali salto mortale!

Što se prestiža tiče, suvremenici su se pitali tko je popularniji, Taine ili Renan. Čukin odgovar na tu dilemu glasi:

Renanova djela većinom je svatko mogao čitati, i pročitavši, staviti na stranu. Tainea neće čitati neg umni ljudi, koji se bave ozbiljnom naukom (37).

O konstataciji da Taineov utjecaj opada, autor iznosi Taineovu izjavu da je i on mislio drugačije od svojih "predšasnika", pa da je normalno da "i njegovi potomci sigurno će misliti drugačije od njega".

Hippolyte-Adolphe Taine (Vouziers, 1828. - Paris, 1893.) inače je dominantna pojava na francuskoj kulturnoj sceni druge polovice XIX. stoljeća. I on je "normalien", tj. student elitne visoke škole za humanističke znanosti École Normale Supérieure. Samosvojan i tvrdoglav nije položio državni ispit (agregaciju) pa službuje po provinciji (Nevers, Poitiers, Besançon), surađuje u vodećim časopisima kao što su Journal des Débats $i$ Revue des Deux Mondes i ubrzo doktorira na basnama La Fontainea (Essai sur les Fables de la Fontaine), 1853. godine, a knjiga Essais sur Tite-Live, objavljena iste godine dobiva Akademijinu nagradu. Tu počinje sjajna znanstvena karijera okrunjena 1878. izborom u Francusku Akademiju.

Teme njegovih brojnih knjiga su književna kritika, povijest i filozofija. Navodimo samo nekoliko naslova: Essais de critique et d'histoire (1855.), Études sur les philosophes français du XIXe siècle (kritika spiritualističke škole) (1857.). Omiljeni filozofi su mu Condillac, Hegel i Vaucherot. Napisao je niz djela o filozofiji umjetnosti u Italiji, Grčkoj i Nizozemskoj. Umjetnost i književnost su za njega "prirodne funkcije čovjeka, "životinjske vrste višeg reda". Genije velikih pisaca odlikuju "majstorske sposobnsti": poetska i govornička, a tim sposobnostima upravljaju (na njih utječu): zemljopisni uvjeti (tlo, klima), rasa, vrijeme i društvena sredina. Tako je Taine utvrdio kriterije i parametre po kojima će procijenjivati književna djela i povijesne događaje. Njegova knjiga Origines de la France contemporaine, u kojoj kritizira jakobince i Napoleona I. izazvala je velike polemike.

Taineov utjecaj na suvremenike, pa i na našeg Čuku dolazi očito iz njegove filozofije umjetnosti i povijesti, iz metodološke sustavnosti pristupa književnom djelu i povijesnim pojavama. U Čukinom fondu nalazimo samo jedan naslov Histoire de la littérature anglaise, ali u 5 svezaka 1 - 5, objavljenih između 1885. i 1887. godine.

Istu metodu i kriterije primjenjuje $\mathrm{u}$ istraživanju povijesnih događaja. Kao što smo već istakli to ne mora značiti da nije čitao i ostala njegova djela, no i u ovih pet svezaka mogao je naći razrađenu i primijenjenu njegovu metodu istraživanja u književnosti. 
U svom članku "Individualizam u književnosti" (Prosvjeta, 1900.) Čuka iznosi svoje stajalište o individualizmu dvjema jasnim rečenicama:

Svaki čovjek kad odabere koje zvanje, dužan je i podvrći se zahtjevima i dužnostima, koje mu ono nalaže i tim se odriče onog diela svoje slobode, koji se s tim zahtjevima i dužnostima ne slaže ("O književnosti": 92).

Očito je autor pri ovoj tvrdnji imao u vidu i svoje svećeničko opredjeljenje. A kad se radi o umjetnosti i umjetniku, onda vrijede sljedeća pravila:

Velika je drskost zahtievati da se čitaoci bave samo našom osobom i našim stvarima. Misli li zaista pisac, da se mi moramo baviti njegovim umišljenim nevoljama ili njegovim nesretnim i prostačkim ljubakanjima, kad oko nas ima toliko realne biede i zla? ("O književnosti": 94)

Da bi lakše razumjeli ovaj navod treba ga smjestiti u kontekst sukoba Mladih i Starih u hrvatskoj književnosti na prijelazu iz XIX. u XX. stoljeće.

Za svoja stajališta nalazi dokaze u francuskoj književnosti navodeći doslovno, bez prijevoda, trojicu eminentnih francuskih pjesnika iz perioda romantizma:

Dieu le veut! dans les temps contraires

Chacun travaille et chacun sert.

Malheur à qui dit à ses frères:

Je retourne dans le désert!

Malheur à qui prend ses sandales

Quand les haines et les scandales

Tourmentent le peuple agité.

Honte au penseur qui se mutile

Et s'en va, chanteur inutile

Par la porte de la cité. (Hugo)

Honte à qui peut chanter pendant que Rome brûle

S'il n'a l'âme et la lyre et les yeux de Néron. (Lamartine)

(...) les nations sont des femmes guidées

Par les étoiles d'or des divines idées. (de Vigny)

Inače, Čuka često navodi francuske kritičare, a pogotovo pjesnike, u izvorniku bez prijevoda. Pretpostavljamo da je to u njegovo doba bilo moguće jer su svi školovani ljudi učili francuski i njime se služili, makar pasivno. Tek ponekad je prevodio njihove tekstove, i to opširno, kao što je to uradio u ovom članku u kojem nalazimo navod dug stranicu i pol (!) u hrvatskom prijevodu. Radi se o izvadku iz članka "Demain" ("Sutra") književnika i kritičara Anatolea Francea, koji počinje rečenicama:

Nema više škola, tradicije ni discipline. Bilo je bez sumnje nuždno doći do ove skrajnosti individualizma. Pitate me, je li dobro ili zlo, što smo do toga došli. Odgovorit ću vam, da je skrajnost uviek zlo..... ("O književnosti": 96-97)

Ovdje ćemo dodati, također u izvorniku, nekoliko francuskih stihova i izreka koje Čuka rabi u svom poznatom radu "Ksaver Šaandor Gjalski" (Iskra, 1891, 8 i $10,78-80,86-88)$ 
...... dans cette vie

Rien n'est bon que d'aimer, n'est vrai que de souffrir. (de Musset)

..... c'est affreux, o mon âme

Rien qu'un portrait très pâle....

Qui lentement meurt dans la solitude,

Et que le temps, injurieux vieillard,

Chaque jour frotte avec son aile rude. (Baudelaire)

On ne peut pas comprendre profondément un être sans l'aimer. (Bourget)

La littérature est une psychologie vivante. (Taine)

A ovdje ćemo se zaustaviti s neprevedenim navodima iz francuske književnosti, koji neka posluže čitatelju da lakše shvati duh višejezičnog Zadra na koncu XIX. stoljeća.

Kada je Ante Tresić-Pavičić pokrenuo u Splitu časopis Novi viek, Čuka je priskočio u pomoć svom kolegi iz isusovačke gimnazije u Zadru svojim prikazima, između ostalog, i iz francuske književnosti. Pronašli smo svega dva koja se izravno odnose na francusku književnost.

"Parnasijanci i Fr.(ançois) Coppée" (Novi viek, 1897., 11-12: 745-748) daje plastičnu sliku vremena s nizom pojedinosti o pokretu i pojedincima, generacijama pjesnika. Tako doznajemo da je još 60-ih XIX. stoljeća Francuskom vladala poezija romantizma (Hugo, Musset, Lamartine, te mlađi: Gautier, Baudelaire, Leconte de Lisle i Banville). U to doba Catulle Mendès, zet Gautiera, okuplja "nekoliko mladih pjesnika koji su imali to zajedničkoga, da su iziskivali u pjesmi najprije savršenu ljepotu forme" (745).

1866. objavili su zbirku Le Parnasse contemporain (Gautier, Baudelaire, Leconte de Lisle, Mendès, Coppée, Sully Prudhomme, Houssaye, Desessart). Tim povodom Paul Arène je spjevao rugalicu i parodiju pod naslovom: Le Parnassiculet contemporain. Tako im je ostao nadimak Parnasijanci (Parnasovci). Pridružili su im se: Heredia, Glatigny Mérat, Valade, Diez, a potom i Anatole France, Mallarmé i Verlaine.

Izvor i vodič za ovaj prikaz bio mu je Paul Bourget (kao što će mu 1901. u Nadi biti Régnier). Paul Bourget (Amiens, 1852. - Paris, 1935.) svoju je karijeru započeo kao pjesnik zbirkom La vie inquiète (1874.) i poemom Edel (1882.) a nastavio studijama Essais de psychologie contemporaine (1883.) i Nouveaux essais de psychologie contemporaine (1885.) u kojima proučava pisce koji su najviše utjecali na svoje suvremenike. Zatim se ogledao kao romanopisac: Cruelle énigme (1885.), Crime d'amour (1887.), Le Disciple (1889.), Un cour de femme (1890.) i Terre promise (1892.), i pripovjedač, zbirkama pripovjedaka L'irréparable (1884.), Pastels (1889.) i Un scrupule (1893.). 1894. izabran je za člana Francuske akademije.

Prvi je reagirao protiv naturalizma u književnosti. Rijetkom pronicljivošću psihologa on je najprije analizirao bolesti svoje generacije, da bi potom tražio uzroke i lijek zabludama i društvenim, političkim i vjerskim problemima svoga doba, braneći odlučno rješenje do kojeg ga je vodilo njegovo vlastito istraživanje: 
povratak monarhiji i katoličkim vjerovanjima. Njegovo djelo je djelo psihologa i moralista. U Fondu nalazimo knjige koje ovdje navodimo u stupcu:

Andrea Cornelis. (Orig. André Cornélis), Milano, Fratelli Treves, 1887.

Un delitto d'amore, (Orig. Crime d'amour), Milano, Fratelli Treves, 1886.

Enimma crudele. (Orig. Cruelle énigme), Milano, Fratelli Treves, 1887.

Études et portraits.... Paris, Alphonse Lemerre, 1895.

Portraits d'écrivains. Notes esthétiques, 1895

L'irreparabile (Orig. L'Irréparable), Milano, Fratelli Treves, 1889.

Menzogne (Orig. Mensonges), Milano, Fratelli, Treves, 1891.

Oeuvres complètes de Paul Bourget. Critique. Paris, Plon, 1899

Essasis de psychologie contemporaine, 1899

Iz gornjeg popisa knjiga uočljiv je broj talijanskih prijevoda francuskih djela.

Za Parnasovce Čuka kaže da su se držali onoga što piše Hugo: Car le mot, qu’on le sache est un être vivant. To su poznati stihovi kojima Hugo još 50-ih godina XIX. stoljeća prethodi vitalističkim, darvinističkim gledanjima na jezik.

U vrijeme dok je pisao svoj prikaz (1897.) parnasovska škola više nije postojala. Tada su već vladali simbolisti. Parnasovci su se razišli. Što je ostalo od Parnassea? Mnogo lijepih pjesama, kaže Čuka, ne spominjući Verlaineov Violon d'automne. Dobra estetska pravila i brigu za ljepotu forme.

Priča o Parnasijancima bila je samo uvod za prikaz književnog djela Françoisa Coppéea, koji je ne davno prije toga postao član Akademije i obratio (vratio) se Katoličkoj crkvi. ${ }^{7}$ Romanopisac, novelist, dramaturg i pjesnik. Predhodne godine objavio je roman Le Coupable.

Prepričavanjem sadržaja tog romana Čuka počinje prikaz Coppéea. Radi se o mladiću, vanbračnom djetetu, skitnici, zatvoreniku koji je živio i radio s kriminalcima. Kad je pušten iz zatvora počinio je grabežno umorstvo i opet dospio pred sud. Tko je kriv za njegovu sudbinu: on, njegov otac ili društvo?

Coppée krivnju svaljuje na društvo. A Čuka zaključuje da ga ovaj roman ne će proslaviti, kao ni prvi roman koji je objavio pod naslovom Toute une Jeunesse, autobiografski roman o životu u Parizu. Zanimanje za Coppéeove romane tumači se zasićenošću Zolinim romanima i uspoređuje ga se s romanom Jack Alphonsea Daudeta. Kritika se nije mnogo bavila njegovim prvim romanom, primjećuje Čuka. Za novele i drame Čuka kaže da ima previše čuvstvenosti čak i sentimentalizma.

\footnotetext{
7 To je doba brojnih obraćenja francuskih književnika i intelektualaca na katolicizam kao reakcija na pozitivizam. Široj javnosti je najpoznatiji slučaj Paula Claudela kome su se pridružili upravo François Coppée, Francis James, Huysmans, Léon Bloy, Charles Morice, Charles Peguy, Ernrest Psichari (unuk apostate Ernesta Renana), Georges Duhamel, Paul Verlaine, Jacques Rivière, Georges Bernanos i mnogi drugi o čemu piše Marijan Oblak 2006: 12. Oblak tu navodi mišljenje Frederica Gugelota da je između 1885. i 1935. zabilježeno 150 takvih obraćenja. Sto godina kasnije u Francuskoj se događa nešto slično: bivši članovi Komunističke partije Francuske i ljevičari po uvjerenju i zanimanju nisu se obratili na katolicizam ili neku drugu konfesiju ali traže - "duhovnost bez Boga", kao npr. Regis Debray ili Edgar Morin. Iznimka je bio svojevremeno član CKKPF Roger Garaudy koji je prešao na islam.
} 
Poezija je jaka strana Coppéea. Čuka prenosi Mendèsovu anegdotu kako je Coppée poslao nepotpisanu pjesmu Fleurs mortelles. Kad je došao osobno po mišljenje, Mendès je rekao: "Vi ste nadaren, ali ne znate ni najosnovnije o svom zanatu." Coppée je tada spalio i stihove koje je bio donio sa sobom i počeo iznova učiti pjesnički zanat. Napisao je brojne zbirke: Promenades Intérieures, Poèmes divers, Le Reliquaire, Récits épiques, Le Cahier rouge, Contes en vers, Les Humbles.

Vješt stihotvorac, omilio učenom svijetu, a "svojim opisivanjem modernog obiteljskog života tičući ganutljivu dramatičnu žicu dopao se i prostoj publici" (747).

Opisuje srednji sloj bez prostota i prozaizma - "un enfant pâle du vieux Paris". Nabrajaju se pariške teme i motivi koje bilježi Coppée - "le plus adroit de nos ouvriers en rimes" (Lemaître).

"Amo tamo o francezkoj novijoj književnosti" (Novi viek, 1898., 1: 374-377) kratki je, sažeti prikaz trenutačnih događanja prema književnim žanrovima.

Najprije književna kritika:

René Doumic (uvaženi kritičar, objavljuje u Revue des Deux Mondes) objavio Études sur la littérature française II. Sljedbenik je Brunetièrea: studija o Anatole Franceu, članak o romanu Le Coupable, oštra ali pravedna kritika Zolinog romana Rome (Rim), izvješćuje Čuka, i dodaje: "Uz Brunetièrea Doumic je najbolje znao svesti na pravu vriednost (naime na ništa) Zolina djela...." (374).

Dodajmo da je René Doumic (Paris, 1860-1937) bio profesor retorike u koledžu Stanislas, objavljivao je u časopisima Moniteur, Journal des Débats, Revue Bleue, Correspondant, urednik je Revue des Deux Mondes od 1916. godine. Održavao je predavanja u Francuskoj, SAD i Kanadi. Član Akademije od 1909. i njezin doživotni tajnik od 1923. Samostalan, ponekad i oštar kritičar. U Čukinoj knjižnicima zauzima vidno mjesto sljedećim naslovima:

Écrivains d'aujourd'hui, 2e ed., Paris, Perrin, 1895

Études sur la littérature française, Paris, Perrin, 1898 (2e série)

Études sur la littérature française, Paris, Perrin, 1901 (4e série)

Hommes et idées du XIXe siècle, Paris, Perrin, 1903

Les Jeunes. Études et portraits, Paris, Perrin, 1896

Druga vijest iz književne kritike bio je Brunetière koji je objavio Manuel de l'historie de la littérature française (I. Srednji viek. II. Klasično doba. III. moderno doba). "On je dakle uveo novu diobu, diobu na književna razdoblja a odbacio staru diobu u viekove" (375).

Čuki se sviđa način prezentacije gradiva: 2 stupa na svakoj stranici, lijevo kritičarev tekst, desno autorova djela, kritike, izvori bibliografski podatci.

Ističući Brunetièreove odlike, Čuka otkriva i svoje sklonosti prema sistematičnosti, preglednosti i metodičnosti u radu književnog kritičara. 
Već smo nekoliko puta imali priliku osvjedočiti se da se u vezi s kritičarskim radom Jakova Čuke najčešće spominje Vincent de Paul-Marie Ferdinand Brunetière (Toulon, 1840. - Pariz, 1906.). I on je bio profesor na École Normale Supérieure (1886.), bio je tajnik pa urednik Revue des Deux Mondes (1893.), što je u ono vrijeme bio važan položaj u kulturnom životu Francuske. Ako tome dodamo da je bio i član Francuske akademije, onda ćemo dobiti zaokruženu sliku o Čukinom omiljenom uzoru. To potvrđuje i njegova knjižnica koja sadrži:

L'Art et la Morale, Paris, J. Hetzel et C., 1898

Discours académique, Paris, Perrin, 1901

Discours de combat, Nouv. série (33 ed.), Paris, Perrin, 1903

Essais sur la littérature contemporaine, Paris, C. Lévy, 1892

Évolution de la poésie lyrique en France au XIX siècle, Paris, Hachette, 1894

L'évolution des genres dans l'histoire de la littérature, Paris, Hachette, 1898

L'idée de patrie, Paris, J. Hetzel, 1896

Nouveaux essais sur la littérature contemporaine, Paris, C. Levy, 1895

Nouvelles questions de critique, Paris, C. Lévy, 1890

Questions Actuelles, Paris, Perrin, 1907

Questions de critique (2e ed.), Paris, C. Lévy, 1889

La renaissance de l'Idéalisme, Paris, Firmin-Didot, 1896

Sur les Chemins de la croyance. Première étape. L'utilisation du Positivisme, Paris, Perrin, 1905.

Variétés littéraires, Paris, C. Levy, 1900.

Brunetièrea odlikuje precizno poznavanje djela i tekstova, čak i sekundarnih. Iznosi opće ocjene teza i ideja. Doprinosi uklanjanju mnogih zabluda, ali su mnoge njegove ideje opovrgnute još boljim poznavanjem činjenica. Logičan je i elokventan.

Zadnje godine života posvetio je moralnim problemima i obrani katoličkih dogmi. O tome je napisao djelo Les raisons actuelles de croire (1901.).

Dvije najkraće vijesti iz područja književne kritike odnose se na Fagueta i Lichtenbergera.

Od Čuke doznajemo da je Emile Faguet (La Roche-sur-Yon, 1847. - Paris, 1916.) objavio knjigu Drame ancien et drame moderne. A od našeg francuskog izvora (Larousse du XXe siècle) doznajemo da je i on završio elitnu École Normale Supériere, da je predavao poeziju na Sorbonnei te da je od 1900. član Francuske akademije. Surađivao je u Journal des Débats u kojem je naslijedio Julesa Lemaîtrea. Pamte ga kao «obrazovanog, živahnog, duhovitog i dovitljivog kritičara».

Čukin fond u Znanstvenoj knjižnici u Zadru bilježi sljedeće naslove njegovih djela: .

Dix-neuvième siècle. Études littéraires, Paris, Lecène, Oudin et C. 1896

Le Libéralisme, Paris, Soc. française d'imprimerie et de librairie,1903

Politiques et moralistes du XIXe siècle, Paris, SFIL, 1899 (1ère sér.) 
Politiques et moralistes du XIXe siècle, Paris, SFIL, 1898(!) (2e sér.)

Politiques et moralistes ... Paris, SFIL, 1900 (3e sér.)

Propos littéraires... Paris, SFIL, 1902

Propos littéraires... Paris, SFIL, 1904 (2e ser.)

Pravi rudnik znanja o francuskom XIX. stoljeću.

Druga je kratka vijest: "Lichtenberger (Henri), objavio knjigu La philosophie de Nietzche". Tome manje poznatom autoru i njegovoj knjizi Čuka je posvetio nešto duži prikaz, a o Nietzcheu će za Nadu iduće godine napisati poseban članak. U Čukinoj knjižnici nalazimo istu knjigu, jedinu tog autora. Spomenimo usput da u njoj nalazimo i djela Nietzchea i Schopenhauera, dva najspornija filozofa onog vremena sa stajališta Katoličke crkve. Očito je Čuka kao vrhunski inelektualac želio o njima informaciju iz prve ruke.

Na kraju članka došla je beletristika.

Najprije braća Marguerite. (Paul i Victor), koji pišu zajedno kao braća Goncourt i Rosny. Objavili su dva romana: Femmes nouvelles (ženski pokret) i Les Tronçons $d u$ Glaive (protiv Zole). Jedini njihov trag u Čukinoj knjižnici je roman Paula Marguerittea, La confession posthume.

Za J. K. Huysmansa, obraćenika, koji je napisao roman La Cathédrale Čuka kaže: "U Francuskoj može se dogoditi lako da čovjek, koji je u prvim svojim romanima pretrpao kala i gnjusobe dodje do vjere a čak i do misticizma" (377).

U Fondu nismo našli ni jedan naslov s Huysmansovim imenom.

Te godine umro je Ferdinand Fabre (bivši sjemeništarac, napomnje Čuka) u 68. godini života, autor romana Ma Vocation, u kojem opisuje razne tipove svećenika. A Jules Lemaître je napisao pozitivnu kritiku o tom romanu u Les Contemporains.

Lemaître (Vennecy, 1853. - Taavers, 1914.), je jedan od Čukinih omiljenih autora, o čemu će posvjedočiti i njegova knjižnica. Doktorirao na temu La Comédie après Molière et le Théâtre de Dancourt. Napušta sveučilište i posvećuje se književnosti. Piše pjesme: Les Médaillons (1880.), Petites Orientales (1883.) i kritike u Revue Bleue $i$ Revue des Deux Mondes, koje objavljuje pod naslovom Contemporains u 7 svezaka (1885. - 1899.). U Francusku akademiju izabran 1895. godine, a od 1898. - 1904. predsjednik je Ligue de la Patrie française i Action française. Dakle, intelektualac angažiran u društvenom i vjerskom pogledu. U Fondu nalazimo očekivane naslove:

Les contemporains, Paris, Lecène, 1892

Les contemporains, Paris, Lecène, Oudin,... 1893 (2e sér.)

Les contemporains, ibid. 1894 (3e sér.)

Les contemporains,.... (4e sér.) 1893

Les contemporains,.... (5e sér.) 1892

Opinions à Répandre, Paris, SFIL, 190-

Théories et impressions, Paris, SFIL, 190- 


\section{Gotovo cijeli niz rasprava o "suvremenicima".}

Vijest je i da je Ferdinand Brunetière održao u Parizu predavanje o nemoralu u umjetnosti. S tom vijesti Čuka zaključuje svoju šetnju po francuskoj književnosti u Novom vieku.

U Viencu (XXXII, 1900.: 249-251) Čuka se osvrnuo na Brunetièreov članak "Discours de combat" naslovljujući svoj prilog istim riječima - "Discours de combat". Sadržaj tog izvornog članka (prema Čukinom prikazu) poklapao se s prilikama u Hrvatskoj, pa je teško ponekad razlučiti što je izvorni tekst a što aluzija na domaće prilike, o čemu smo prethodno govorili vezano za suprotstavljena mišljenja Glavaša i Milanje. Članak počinje prikazom i nabrajanjem imena francuskih kritičara. U nastavku dajemo nekoliko širih navoda da čitatelj može donijeti svoj vlastiti sud, uz napomenu da u njima može naći i sintezu Čukinog književno-kritičarskog creda, te da je ovo uz njegov programatski članak "Naše književne nevolje i kritika" iz 1891. njegov najpoznatiji prilog hrvatskoj književnoj kritici. Ujedno se ispričavam što ću se na idućih nekoliko stranica poslužiti metodom koju kritičari zamjeraju Čuki: da citate iz svojih francuskih izvora jednostavno lijepi na svoja stajališta o hrvatskim književnim prilikama.

Od književnih kritičara u naše doba bez sumnje najveći utjecaj na razvoj književnosti imali su Taine, Vogüé i Brunetière. Taine je uveo realizam, koji je svršio naturalizmom, i pod starost uvidjevši, do čega je dovela knjigu njegova nauka, htio ju je popraviti. Vogüé, kako je svakomu poznato, knjigom o ruskom romanu započeo je novo razdoblje u povijesti književnosti, a Brunetière, srušivši naturalizam i bodreći psihološku školu i boreći se proti staroj formuli "l'art pour l'art", pripomogao je silno preporodu idealizma i velikom pokretu, koji ne će da umjetnost bude odieljena od čovjeka, od života, od životnih moralnih i družtvenih pitanja ("O književnosti": 117).

Ovdje se najbolje vidi da je književna kritika postala samostalna disciplina. I ne samo to, ona je već 1900. "pervertirala", u smislu da se smatrala kreatoricom književnih smjerova, ona snaga koja određuje kako će se pisati Iz tog pervertiranog vidika stvara se i slika idealne kritike, koju nalazimo na istoj stranici članka.

Ima mnogo kritičara, koji kao i Brandès analizuju, ali ne ruše niti grade, ne lieče niti ubijaju, a malo ih je sretnih, kao on, koji mogu odkriti svietu kojega svog zemljaka, koji je zavriedio, da ga sviet upozna.

Ovo će valjda i biti u poviesti najveća zasluga (bez prave zasluge) Brandèsova. Takvim kritičarima ja predpostavljam one, koji ruše, što ne vriedi, a grade nešto bolje, koji ubijaju i lieče, jer ako je na svietu zabranjeno ubijati, to je dopušteno u književnoj republici. U njoj ubojstvo može biti sveto djelo umjesto zločina. Zato i ljubim Brunetièrea, koji je dandanas najveći predstavnik ove potonje vrsti kritičara (118).

U pitanju su (na domaćoj sceni), izgleda, bile književne teme u Hrvatskoj, pa bi se na hrvatske književnike trebala odnositi Čukina rečenica:

Zašto da književnici sami budu stranci u svojoj domovini i da ne vide i da ne čuju, što nas tišti, čega trebamo?

Radi li se ovdje o sukobu Starih i Mladih, o pojavi hrvatske moderne? U pitanju je bilo poimanje tradicije i odnos prema njoj. To sudimo po citatu iz Brunetièrea koji Čuka iznosi kao "argumentum auctoritatis". 
La tradition, veli Brunetière, pour nous, ce n'est pas ce qui est mort, c'est au contraire; ce qui vit; c'est ce qui survit du passé dans le présent; c'est ce qui dépasse l'heure actuelle; et de nous tous, tant que nous sommes, ce ne sera, pour ceux qui viendront après nous, que ce qui vivra plus que nous (122).

U tom svijetlu ocjenjuje ondašnje prilike i ugled svojih suvremenika književnika:

Mi imademo dandanas bez sumnje vriednih književnika, koji ne zaostaju ni za najboljima ilirske dobe, a ipak njihovo ime nije popularno, kao što ono starih iliraca, ato zato, što su se udaljili od tradicije i odtuđili se narodu (124).

Govoreći o vezi između tradicije i rodoljublja, kritizira ulogu političkih stranaka.

Kod nas se obično rodoljublje priznaje samo pristašama jedne ili druge političke stranke, kao da je ljubav domovine privilegij pojedinih stranaka. Političke stranke mogu nas jedino dieliti i razcjepkati, a okupiti nas može i sjediniti samo ideja domovine (125). idejama.

I tada upućuje na Brunetièrea. Iz te upute se vidi koliko je Čuka odan njegovim

Neka mi oproste čitaoci, što mjesto da im govorim o Brunetièreovoj knjizi, pišem svoj Discours de combat (govor prije bitke). Napisati kritiku te knjige ja ne bih mogao, jer ja pristajem podpuno uz pisca, a govoriti o pitanjima tako važnim kao što su: preporod idealizma, umjetnost i moral, ideja domovine, neprijatelj narodne duše, potreba vjere i genij naroda, ja ne bih znao ni izdaleka onako, kako Brunetière, a kad bih htio priobćiti izvadak iz njegovih govora, ne bih znao što ispustiti, jer je sve važno promišljeno i na svom mjestu. Dao Bog, te preveo tkogod bar tri od njegovih konferenca: L'art et la morale, L'idée de Patrie, te Les Ennemis de l'âme française. Po ovoj zadnjoj mogli bismo lako upoznati i neprijatelje hrvatske duše, a tih ima mnogo krivih i nedužnih (125).

Književo ozračje u Hrvatskoj kako ga u svom prilogu prikazuje Čuka podsjetilo me je na interpretaciju Nazorova "Cvrčka" od strane profesora Serafina Mičića u Pazinu 1959. godine. Ta mi se interpretacija usjekla duboko u pamćenje tako da se i danas sjećam njezinih osnovnih misli. A te misli su otprilike sljedeće: Jedino se kod Dragutina Domjanića može opravdati nostalgija i pesimizam. On je pripadnik plemićkog sloja koji propada i odlazi s društvene scene. Svi ostali književnici toga doba su pripadnici srednje klase ili su došli sa sela i pesimizam nije svojstven njihovom društvenom statusu. Jedino je Nazor donio sa sobom iskonsku snagu prirode ovjekovječene u poznatim stihovima: "I crvrči, cvrči cvrčak na čvoru crne smrče" i "O šipražje i ševarje te zemlje naše".

1901. godine Čuka je objavio u dva nastavka članak "Novije pjesništvo u Francuskoj" u sarajevskoj Nadi (1901/I: 52-54, 69-70). Na samom početku svog članka Čuka navodi relevantnu literaturu o stanju u francuskoj književnosti, u Francuskoj i u Hrvatskoj, da bi onda prešao na prikaz "razvoja i pravaca novije francuske poezije, onako kako je to učinio u vrlo krasnom govoru poznati francuski pjesnik Henri de Régnier",8 ali ne navodi naslova svog izvora. Sam prikaz je jedna vrsta pjesničke šetnje francuskom poezijom XIX. stoljeća. Ne znamo kome

${ }^{8}$ Henri de Régnier (Honfleur, 28.12.1864 - Pariz, 23.5.1936), romanopisac i pjesnik blizak simbolistima. Član Francuske akademije. U Fondu nalazimo samo jedan njegov naslov - Figures et Caractères. 
dugujemo slikovitost prikaza: Régnieru ili Čuki? Evo nekoliko širih izvoda izvoda da bi se moglo uživati u Čukinom (Régnierovom) stilu pisanja književne kritike:

Muza koja bijaše zaspala koturnom na nogama i vlasuljom na glavi, zavijena u tijesne klasične čipke, probudila se pri lijepu suncu godine 1830., sred prirode - bosonoga, svježa, rumena u licu, puna života, čežnje i strasti. Ona se zavila sjajnim šarama. Hugo ju je vodio svuda uza se. S njime je ona proputovala svijet oblika i slika. Lamartine ju je skrio u prozračne sjene, Musset ju je poveo uza se i sio je za so pod zelenu lozovu sjenicu. Gautier ju je nakitio kamejima i emaljima. Vigny ju je podigao do samotnih bregova i htio ju zadržati kod čobanske kolibe, ali ona je utekla, išla dalje svim putevima i nabasala višeput na grubo. Dok se tako klatarila, sretoše je Parnasijanci godine 1864. Oni su htjeli preurediti lijepu samotanku i obogatiti ju svojim darovima. Obukoše je u lijepa odijela, pravilno skrojena i čvrsto sašivena. Leconte de Lisle ponudio joj starinsko zrcalo i nataknuo joj na ruke barbarsko prstenje, Baudelaire ju parfimrao čudnim mirisima, Théodore de Banville stavio joj u ruke kitu vesela cvijeća (52).

\section{Iz pjesničko-evolucionističkog opisa prelazi se u pjesničko-kritičarski prikaz:}

Parnasijanci napokon bili su sasma svjesni svoje uloge takovih nastavljača. Gledajte samo kako se poslušno dive V. Hugu. Znanstveno-filosofski stihovi Sully-Proudhommea, što u ostalom nijesu baš njegova najbolja stvar, dolaze od Huga, koji priopćuje Coppéeu buržoaski sentimalni i pučki lirizam. Dierx je Lamartinijanac, Leconte de Lisle srodan je Vignyu, Baudelaire i Heredia imadu takogjer romantizam u sebi. Ali ako ćemo pravo, Parnasijanci bili su vrijedni umjetnici. Romantizam nadahnuća nadomjestili su romantizmom umovanja. ......

Parnasijanci bili su dobra djeca, jer Parnas bio je više sinom nego ocem. On ne ragja, on je svrha, konac nečega, ali on je ipak nešto. Vigja se to dobro od god. 1875. do 1885. - u doba ružno za poeziju. Godine 1875. djelo Parnasijanaca je gotovo. Leconte de Lisle, ostarivši, ne izdaje ništa. Sully-Proudhomme gubi se. Coppée se vulgarizira. Armand Silvestre opetuje neprestano istu zvučnu, ali praznu pjesmu. Catule Mendès samo se postostručuje. On je Hermes Parnasa. Heredia lijeno i polagan urezuje sonete svojih Trofeja, koji ne će ugledat svjetlo neg kasnije (52).

Nakon Parnasa slijedili su dekadenti a za njima su došli simbolisti.

Stil dekadanse nije ništa drugo, neg umjetnost koja je došla do onog najzadnjeg stepena zrelosti, što ga proizvagjaju civilizacije, koje staraju, pri zapadu. Stil rafiniran, kompliciran, znanstven pun nijansa i istraživanja, koji razmiče uvijek granice jezika, uzimajući riječi iz svih rječnika... (Régnier)

A o manama nešto dalje, po svoj prilici Čukine misli, nalazimo:

Neki bizantinizam i pretjerana tančina bijahu dakle glavne mahne Dekadenata, mahne više prividne neg realne, više prolazne neg ustrajne, koje u ostalom izvinjava žarka želja za novostima i nada da će se u njoj proširiti granice i vlast poezije i da će se u njoj odgojiti rijetko mirisno i neobično cvijeće (52).

Kako Régnier nije pisao o simbolistima, Čuka se oslonio na neke druge francuske kritčare. Prije svega na Brunetièrea koji se prvi bavio simbolistima te na Rémy de Gourmonta9 $^{9}$ koji definiciju simbolizma izvlači iz njegove etimologije:

\footnotetext{
${ }^{9}$ Rémy de Gourmont (1858. - 1915.), knjižničar u Bibliothèque Nationale de France. Surađivao u Mercure de France. Romanopisac, bavio se književnom i filozofskom kritikom. Jedan od najboljih poznavatelja simbolista. U Fondu se nalazi njegova knjiga Dialogue des amateurs sur les choses du temps.
} 
... individualizam u književnosti, slobodu umjetnosti, zabačenje naučenih formula, težnju za onim što je novo, čudno pa i bizarno; a može značiti i idealizam, prezir socijalne anegdote, antinaturalizam (69).

Predstavnici dviju osnovnih odrednica bili bi: Verlaine (individualizam) i Mallarmé (idealizam). Sam idealizam u simbolista Gourmont definira:

Obzirom na svijet subjekta koji misli - svijet, sve što je njem izvanjsko, ne postoji nego prama ideji koju on stvara o njem. To jest svijet je moja utvara reprezentacija. Ja ne vidim ono što jest; ono što jest - jest ono što ja vidim (69).

Po mišljenju Čukinih francuskih izvora, francuska poezija do simbolista bila je deskriptivna, autoritarna. "Simbolizam pak više potiče čitatelja da surađuje da otkriva smisao simbola koji su kao natuknice posijani u pjesmi. Oni upućuju na mitove i mitologiju, jer svaka ideja ima svoj, ili točnije - svoje simbole" (70).

Simbolisti, kao autentični individualisti napravili su i preokret u metrici: uveli su slobodni stih.

Svoj prikaz završava porukom mladim hrvatskim pjesnicima:

Želim pak našim mlagjim pjesnicima, da iz ovih razmatranja nauče, kako nije ništa vječno na - svijetu, ni - u književnosti. Kad misli čovjek, da je rekao zadnju riječ u kom pitanju, dogje drugi, koji mu dokazuje - da ima krivo! A tako će valjda biti uvijek, i posljednja riječ ne će se nikada izreći (70).

Ovo je u kontekstu sukoba Starih i Mladih u Hrvatskoj, poruka pomirenja, poruka da ništa nje stalno ni vječno u razvoju pjesništva, što je sasvim u skladu s evolucionističkim pristupom Tainea, rodonačelnika francuske književne kritike. Čuka ne spominje mnoga imena simbolista. Spomenuo je Verlainea i Mallarméa, dodao je još Gregha, Guérina i Jamesa. Ne spominje uopće Rimbauda, ni ovdje ni u svojim drugim prikazima. U jednom drugom prikazu navesti će još kao simboliste Adama, Barrèsa, Régniera, Griffina, Gourmonta, Gidea, Kahna, Mauclairea (Cf. "O književnosti": 60).

Taj prilog u Nadi bio je ujedno i pretposljednji takav prilog u nekom časopisu izvan Zadra prije prekida bavljenja kritikom. Naime, posljednji njegov prilog $\mathrm{u}$ jednom nezadarskom časopisu objavljen je u Rivista politica et letteraria pod naslovom "Il conte Tolstoj e le sue opere", 1903. U međuvremenu je napisao 15 priloga u časopisu Glasnik Matice Dalmatinske kojem je bio glavni urednik.

Od francuskih ili frankofonih književnika i kritičara koji se spominju u vezi s Jakovom Čukom, odnosno kritičarom Jakšom Čedomilom, a čija imena nalazimo u Fondu, navedimo još Georges-Jacques-Marie Pellissiera (1852. - 1918.) zastupljenog u Fondu naslovima Mouvements littéraires au XIXe siècle i Essai de littérature contemporaine; Edouarda Roda (1857. - 1910.), švicarskog književnika i sljedbenika Emilea Zole čija se knjiga Nouvelles études sur le XIXe siècle također nalazi u Čukinom fondu, u kojem nalazimo i Anarchie littéraire Charlesa Recolina.

To bi bilo ono najvažnije što se može podvesti pod pseudonim Jakša Čedomil ili Čedomil Jakša kao sinonim za književno-kritičku djelatnost dr. Jakova Čuke, a objavljeno je za njegova života i tiče se njegovih dodira s francuskom književnosti 
i književnom kritikom, s posebnim osvrtom na francuske autore i njihova djela zastupljena u Fondu Čuka u Znanstevnoj knjižnici u Zadru. No naša okvirna tema nas je ponukala da zavirimo i u Čukinu neobjavljenu ostavštinu. Tamo je pronađen snopić rukom ispisanih listića prijevoda nekog francuskog djela. Prvi je o tome pisao A. R. Glavaš u već spomenutom djelu. Kao što smo to već na početku ovoga rada najavili, Glavaš navodi da je u Čukinoj pismenoj ostavštini nađen rukopis nedovršenog prijevoda francuskog romana Lettres d'un curé de canton, a Beritić spominje rukopis nedovršenog i neobjavljenog prijevoda nekog francuskog romana, ne navodeći točnije podatke o izvorniku. Glavaš u svojoj knjizi na strani 219, u popisu neobjavljenih radova, navodi: Pisma jednog župnika, prijevod s francuskoga, ali nije označeno, kojega autora prevodi, ni kad je počeo prevoditi. Iz pisma, crnila i papira može se zaključiti, da je prevodio u vrijeme, kad je pisan članak "Naša zadaća". Stil prijevoda ima sve karakteristike Čedomilova pisanja. Prijevod ima 58 malih listića. To je prijevod knjige Lettres d'un curé de canton (1898.) od Yves le Querdeca.

Autor ispravno tvrdi da nema imena autora francuskog izvornika niti datuma početka rada na prijevodu. Vjerojatno je ispravno prebrojio listiće, a kako je imao širi uvid u Čukine rukopise, vjerojatno je usporedba crnila i papira s rukopisom spomenutog članka ispravna. Međutim, Glavaš nije prepisao cijeli naslov koji u rukopisu glasi Pisma jednog župnika na selu (Lettres d'un curé de campagne). I tu bi identifikacija francuskog izvornika bila rješena. Naime, početnih nekoliko rečenica Čukina prijevoda glasi:

"Saint-Julien 4 listopada

Dragi prijateliu,

Evo me da se odužim obećanju i da ti pričam čedan život župnika. Kazat ću ti sve svoje nade i svoja razočaranja, svoje osnove i svoja kolebanja, svoje uspjehe i svoje neuspjehe. Moći ćeš, do prigode, dati mi kakav dobar savjet. Pripovijedati ću ti male zgode i nzgode svog župničkog života. Nadam se da neće biti u njima niti šta izvanredna, a niti šta." glasi:

Naprotiv, početak romana koji Glavaš navodi (Lettres d'un curé de canton) Saint-Maximin, le 15 octobre

Bien cher ami,

À peine arrivé je vous écris. Je débarquai hier matin à la gare vers dix heures. Au sortir du wagon je vis venir à moi un jeune abbé qui s'avança courtoisement, me salua, d'un très respectueux: "Bonjour, Monsieur de Curé", et, se présentant lui-même, fit tous ses efforts pour se rendre maître de ma valise. C'était M. l'abbé Firmin, mon vicaire. (Yves le Querdec, Lettres d'un curé de canton, Paris, Victor Lecoffre, 1898.)

Da se ne radi o navedenom romanu vidljivo je već iz samog mjesta i datuma pisma, pa ne ćemo ni prevoditi francuski tekst.

Sada se nameće pitanje je li prijevod Pisama jednog seoskog župnika Yvesa le Querdeca, objavljen u Zadru s potpisom Zbora bogoslovne mladeži 1917., nastavak Čukina prijevoda ili potpuno novi prijevod. Jer, normalno bi bilo zaključiti da se radi o nastavku Čukinog prijevoda budući da je tih godina I. svjetskog rata Čuka boravio 
u Zadru iako o tome do sada nemamo ništa objavljenoga. Čitatelju prepuštamo da početak Čukinog prijevoda usporedi s početkom objavljenog prijevoda, koji počinje ovako:

Sv. Julijan 4. listopada

Dragi moj prijatelju!

Evo me da ispunim svoje obećanje i da ti ispripovjedim skromni život jednoga župnika, sluge Božjega, kako obično kazivaše gospodin potpredsjednik. Otkrit ći ti svoje nade i razočaranja, svoje osnove i kolebanja, uspjehe i neuspjehe. Do prigode moći ćeš mi dati kakav dobar savjet. Pripovijedit ću ti sve i najmanje zgode svog župnikovanja. Mislim, da ne će biti ništa izvanredna, ali niti neugodna.

Inače, Yves le Querdec je drugo ime za Georges-Pierrea Fonsegrive-Lespinassea, (Dordogne, 1852. - Paris, 1917.), profesora filozofije i direktora katoličkog dvotjednika La Quinzaine (od 1896.), koji je napisao brojne rasprave iz filozofije, etike i društvenih problema: Essai sur le libre arbitre (1887.), François Bacon (1892.), Causalité efficiente (1893.), Mariage et l'union libre (1904., Nagrada Akademije), Morale et Société (1907.) i État moderne et la neutralité scolaire (1909.). Od književnih djela koja je napisao u Čukinoj knjižnici nalazimo tri naslova: Lettres d'un curé de campagne (1895.), Lettres d'un curé de canton (1896.) i Le Fils de l'Esprit (1905.). Mnogo kasnije objaviti će i roman Le mariage du docteur Ducros kojeg nema u Fondu.

Možemo zaključiti da Glavaš nije usporedio rukopis prijevoda s francuskim izvornikom nego je samo nagađao. Čukina ostavština je tada još bila u privatnom posjedu Marina Čuke i nije bila tako dobro razvrstana kao danas u Fondu Čuka u Znanstvenoj knjižnici u Zadru. Lako je zamisliti da Glavaš tu knjigu nije imao u ruci.

\section{RAZOČARANJE (ILI EFEKT JEDNOSMJERNO PROZIRNOG STAKLA)}

Čuka je uložio golem trud (i novac) u svoj rad na književnoj kritici s očitim rodoljubnim ciljem nazočnim u svakom njegovom prilogu, da hrvatsku književnu javnost upozna s dostignućima stranih književnosti (talijanske i francuske), koliko na stvarateljskom planu toliko i na planu kritike koja je pratila (i pokušavala usmjeravati) književno stvaralaštvo. Isto tako je nastojao strano čitateljstvo (talijansko i francusko) upoznati s dostignućima hrvatske književnosti. Za sav taj trud dobio je, u materijalnom pogledu, svega nekoliko honorara, a u intelektualnom poneko priznanje, ali i velika razočaranja.

- Razočarao se što biskup Mahnić nije bio zadovoljan njegovim govorom (O lijepoj knjizi) na Kongresu katolika u Zagrebu 1900. godine, povodom čega je rekao da ga je održao kao "gorljivi pristaša Brunetièrea" čija kritika najbolje odgovara kršćanskim načelima i kršćanskom pravcu (Uspomene, 388). Redovito se spominju napadi Hrvatske straže na njega, ali isto tako stoji činjenica da je Čuka bio pretplatnik istog časopisa od 1903. - 1908. U Fondu nedostaje samo 1909. godište tog časopisa. Stoji i činjenica da je "fra Čedomil" objavio u Hrvatskoj straži 1904. pjesmu "Novom ljetu". 
- Istom prilikom je osobno upoznao mnoge pisce o kojima je pisao: Gjalski, Nikolić, Hranilović, Dežman. Osobito ga je razočarao Gjalski kome je on bio posebno sklon. Jedino ga je oduševio Kranjčević, s kojim je nastavio suradnju.

- Najviše se na početku te iste godine razočarao u Brunetièreu. Evo što o toj zgodi piše u svojim Uspomenana:

Napisah prikaz o hrvatskom romanu talijanski i poslah Jeretovu /u Pariz/, da ga francuski sa Jelavićem prevede i da se zauzme ne bi li Brunetière tiskao ga u Revue des Deux Mondes. Jadan Jeretov zauzeo se, preveo sa Jelavićem, pošao u Leroy Beaulieu. Ovaj obećao pomoć i pošao Jeretov u Brunetièrea. Brunetière pridržao rukopis, pročitao i tad rekao Jeretovu, da onako se uvredljivo nema pisat odmah s početka, jer u uvodu bijah natuknuo da svijet ne pozna hrvatsku knjigu, a on mislio da je uvreda reć Francuzima da ne poznavaju i da ne hvale što ipak zaslužuje hvalu i poznanje. Rekao, da bi trebalo radnju tako i tako preurediti i u opće dao toliko naputaka da Jeretov nije ih držao ni na pameti, jer, kako mi je pisao, on ostao malo pokunjen, pošto nije to očekivao i mislio da će ići po loju. A i ja ostao pokunjen i zabacio rukopis na vieke, te ostao netiskan u mojem pisaćem stolu. Jednom kašnje ga poslah na uredništvo "Revue" u Pariz, koja je donašala preglede raznih tudjih književnosti. Uredništvo vratilo rukopis. hvaleći ga i žaleć da ga ne može tiskat, jer da ne bi imao važnosti za francusku publiku (Lukić 1958: 389).

Ova Čukina pariška zgoda neodoljivo podsjeća na iskustvo Petra Šegedina u Parizu 1972. u susretu sa svojim nekadašnjim starim znancima iz vremena kad je bio jugoslavenski ataše za kulturu u Ulici fazanerije 16 (Rue de la faisanderie) pedesetih godina XX. st. Te godine su ga i Klara Malraux r. Goldmann i Pierre Emmanuel (katolički intelektualac i francuski akademik) otpravili gotovo s kućnog praga kao "genocidnog Hrvata", njega koji je poslije Karađorđeva pobjegao najprije u Francusku a potom u Njemačku bojeći se za svoju sigurnost i slobodu. Šegedin je te susrete opisao i objavio u svom djelu U carstun ponesenih duša.

U svjetlu dvaju gore opisanih slučajeva tim veće se pokazuju zasluge JeanLouisa Depierrisa koji je djelovao u oba smjera, prikazujući Hrvatima francuske književnike i slikare, a Francuzima hrvatske pjesnike i slikare. ${ }^{10}$

Njega je autor ovih redaka osobno imao priliku i čast predstaviti zadarskom općinstvu lipnja 1971. godine u Matici hrvatskoj u Zadru. Sjećanjem na JeanLouisa, istinskog prijatelja Zadra i Hrvatske, htjeli bismo završiti ovo izlaganje Jakši Čedomilu, alias Jakovu Čuki, ali nam je još prikazati još jednu epizodu pred kraj života našeg autora koja mu je treba donijeti neko zadovoljstvo, o kojem bar zasad ništa ne znamo.

\section{ZADOVOLJŠTINA}

Četiri godine prije smrti, koncem 1924., Čuka je doživio jednu vrstu zadovoljštine. Na njegovu adresu u biskupijskom ordinarijatu u Splitu stiglo je pismo s oglednim primjerkom iz uredništva časopisa Nouvelles Religieuses (Vjerske

\footnotetext{
${ }^{10}$ Od pjesnika prepjevao je Mihalića, Zidića, Parun i dr., objavio antologiju hrvatske poezije i preveo antologiju ratne poezije U tom strašnom času (En ces temps du terrible) u suautorstvu s Đurđom ŠinkoDepierris. A od slikara francuskoj je javnosti predstavio Lackovića Croatu, M. Skračića i Šiška.
} 
novosti). Pismom mu se želi svratiti pozornost na časopis kome je poslanje da bude u službi katoličkih interesa odgovarajući na potrebe izražene sa svih strana zbog nedostatka vjerodostojnih informacija. Iz pisma se doznaje da taj časopis uređuje vlč. Janvier, propovjednik u Notre-Dame de Paris, da je namijenjen intelektualnoj međunarodnoj eliti i želi biti veza među katolicima cijelog svijeta, objavljujući dotad neobjavljene dokumente. Drugim riječima želi pisati iz dana u dan vjersku povijest naroda uz potporu visokog klera i Rima.

Od primatelja se samo očekuje da časopisu pruži "svoju dragocjenu pomoć, simpatiju i blagonaklonu zaštitu". Ne znamo je li Čuka odgovorio na ovo pismo, je li surađivao u časopisu. U svakom slučaju, ma da se radi o visoko učtivom epistolarnom stilu, on je uvršten u međunarodnu intelektualnu elitu od strane jednog francuskog časopisa. Nije to bila Revue des Deux Mondes, ali se ipak radilo o pariškom časopisu!

\section{LITERATURA}

A n t i ć, Vino. 1958. "Kranjčevićeva pisma Jakši Čedomilu". Riječka revija 6: 396409.

A n t i ć, Vinko. 1959. "S.S. Kranjčević i Jakša Čedomil". Zadarska revija 3,4: 286298, 390-399

B e r i t i ć, Nada. 1968. "Čukina biblioteka". Zadarska revija 9. XVII. br. 6: 465-

B i e t, C; B rig h ell i, J. - P, Rispail. Guide des auteurs de la critique, des genres et des mouvements. Magnard.

Č e d o m i l, Jakša. 1943. Prikazi i rasprave. Zagreb: HIBZ.

Če d o m i l, Jakša. 1944. O književnosti. Zagreb: HIBZ.

Č e d o m i l, Jakša. 1891. "Ksaver Šandor Gjalski". Iskra, 878-80, 10: 86-88.

Č e d o m i l, Jakša. 1893. "Hipolit Taine". Iskra 5-6: 36-37.

Č e d o m i l, Jakša. 1900. "Discours de combat". Vienac, br. 16

Č e d o m i 1, Jakša. 1901. "Novije pjesništvo u Francuskoj". Nada 4: 52-54; 5: 69-70.

Č e d o m i l, Jakša. 1897. "Parnasijanci i F. Coppée (knjiž. pismo I) ". Novi viek 1112: 745-748.

Č e d o m i l, Jakša. 1898. "Amo tamo po francezkoj književnosti (knjiž. pismo IV)". Novi viek 6: 374-377.

Č u k a, Marin. 1958. "Iz života Jakše Čedomila - Sjećanja". Riječka revija 6: 392395.

Ču k a, Jakov. Spisi. Spisi iz ostavštine, III. Objavljeni i neobjavljeni radovi, 1 (ZKZD: 163936, MS 1097/III/1) 
D o r k i n, Mladen. 1990. "Jakša Čedomil o talijanskom romanu". Zadarska revija 39/ 1: 13-22, Per. D 594

D o rk i n, Mladen. 2011. Časopis "Iskra" (1884-1887; 1891-1894). Zadar: MH.

Fr a n i ć, Ante. 1968. "Jakša Čedomil". Zadarska revija 6: 458-464.

Gla vaš, Andrija Radoslav. 1942. Jakša Čedomil.Osnivač moderne hrvatske kritike. Zagreb: Hrvatska državna tiskara.

Ke r o, Pavao. 2001 "Mons. dr. Jakov Čuka (1868-1928)". Papinski hrvatski zavod svetog Jeronima (1901-2001), 428-443. Sign.: 252621 Mis 1959c. C 44697

Košutić-Brozović, Nevenka. 1976. "Uloga Zadra u književnom životu hrvatske Moderne", Radovi Filozofskog fakulteta u Zadru, 1975/1976, Razdio filoloških znanosti, 9, 271-287.

Le Que r d e c, Yves. 1898. Les lettres d'un curé de canton. Paris: Victor Lecoffre.

L u k i ć, Berislav. 1958. "U povodu 30. godišnjice smrti Jakše Čedomila". Riječka revija 6: 369-391 (Uspomene, 374-390).

M i l a nj a, Cvjetko. 1985. Jakša Čedomil. Zagreb: Zavod za znanost o književnosti, Sveučilišna naklada Liber.

Mil a nj a, Cvjetko. 1993. "Jakša Čedomil". Zadarska smotra 42, 1-2: 367-382 (Per. D 594).

O b l a k, Marijan. 2006. Paul Claudel, obraćenik, diplomat, književnik. Zadar.

R a d o s, Zvjezdana. 2011. "Hrvatska književnost u Zadru u vremenu austrijske uprave". U: Zadar za austrijske uprave. Zadar: Matica hrvatska - Ogranak u Zadru: 789-951.

R a v li ć, Jakša. 1958. "Jakša Čedomil". Zadarska revija 6: 299-304.

\section{Les Sources et les Modèles Français de Jakov Čuka \\ (D'APRÈS LES SOURCES DU FONDS ČUKA DÉPOSÉ À LA BIBLIOTHÈQUE SCIENTIFIQUE DE ZADAR)}

Le travail présente l'œuvre du critique littéraire croate Jakov Čuka (1868 1928), mieux connu dans les milieux littéraires sous le pseudonyme Jakša Čedomil, à la lumière de ses modèles français (Taine, Brunetière, Saint-Beuve et autres), auxquels il se référait dans ses critiques et analyses, et d'après les sources qui se trouvent au Fonds Čuka, déposées à la Bibliothèque scientifique de Zadar, qui garde les œuvres de 112 auteurs français et 290 titres en français ou en traduction (italien, allemand, croate). La connaissance de ces auteurs lui a mérité le titre du «fondateur de la critique littéraire croate». Le Fonds même présente une source riche des connaissances sur la littérature française du XIXe siècle.

Mots-CLÉs: Jakov Čuka, Jakša Čedomil, la critique littéraire, la littérature française. 